\title{
Postrzeganie społecznej odpowiedzialności biznesu w bankach spółdzielczych przez ich klientów
}

\begin{abstract}
Anna Nowacka*
Streszczenie: Koncepcja społecznej odpowiedzialności biznesu wpisuje się w strategię działania banków spółdzielczych od momentu ich powstania. Spółdzielczy charakter tych instytucji a zarazem chęć konkurowania z innymi podmiotami na rynku finansowym odzwierciedlają główne założenia idei CSR. Banki spółdzielcze realizując swoją misję i wizję starają się połączyć cele komercyjne ze społecznym wymiarem swojej działalności.

Głównym celem opracowania jest zaprezentowanie opinii klientów banków spółdzielczych na temat realizacji idei społecznej odpowiedzialności biznesu przez te instytucje. Autorka próbuje odpowiedzieć na pytanie, czy klienci dostrzegają społeczne aspekty funkcjonowania banków spółdzielczych, jak oceniają ich podejście do prowadzenia biznesu.

Podstawą empiryczną problematyki poruszonej w artykule jest studium literatury przedmiotu oraz wyniki badania ankietowego przeprowadzonego wśród 132 klientów wybranych banków spółdzielczych. Pytania dotyczyły: inicjatyw społecznych podejmowanych przez banki spółdzielcze, form wsparcia udzielanych przez te instytucje oraz udziału klientów w imprezach sponsorowanych przez banki spółdzielcze. W artykule wykorzystano następujące metody opracowania wyników badania: wskaźniki struktury i test zgodności chi-kwadrat.

W oparciu o wyniki przeprowadzonego badania sformułowano ogólne konkluzje. Najważniejszą z nich jest fakt, że klienci dostrzegają inicjatywy społeczne podejmowane przez banki spółdzielcze. Pozytywnie oceniają zaangażowanie tych instytucji w promowanie imprez kulturalno-oświatowych oraz wspieranie i dotowanie organizacji społecznych i charytatywnych. Idea CSR realizowana jest również poprzez proces edukacji finansowej społeczności lokalnej, a zwłaszcza młodzieży.

Słowa kluczowe: banki spółdzielcze, społeczna odpowiedzialność biznesu, ekonomia społeczna, klienci.
\end{abstract}

\section{Wprowadzenie}

Pojęcie społecznej odpowiedzialności biznesu nie ma jednoznacznej definicji w literaturze przedmiotu. Zauważalna jest ewolucja interpretacji tego pojęcia, zarówno w ujęciu teoretycznym, jak i praktycznym. W latach 50. XX wieku, kiedy zaczęto używać terminu „społeczna odpowiedzialność biznesu", twierdzono, że menedżerowie biznesu mają obowiązek prowadzenia takiej polityki postępowania i podejmowania decyzji, która jest pożądana z punktu widzenia celów i wartości społecznych [Bartkowiak, 2011, s. 15].
W kolejnych latach podjęto liczne próby doprecyzowania tego pojęcia, szczególnie w kontekście różnych wymiarów CSR (Corporate Social Responsibility - społeczna odpowiedzialność przedsiębiorstw/biznesu). Najczęściej dyskutowane i używane wymiary społecznej odpowiedzialności biznesu dotyczą: ujęcia z punktu widzenia interesariuszy, wymiaru społecznego, ekonomicznego, śro-

\section{* dr Anna Nowacka}

Zakład Finansów i Rachunkowości Wydział Nauk Ekonomicznych i Informatyki Państwowa Wyższa Szkoła Zawodowa w Płocku e-mail: prorektor@pwszplock.pl 
dowiskowego oraz wymiaru dobrowolności. W definicjach CSR akcentuje się poświęcenie przez przedsiębiorstwa części zysków na rzecz społecznego interesu [Benabou, Tirole, 2010, s. 2].

Według A. B. Carrolla społeczna odpowiedzialność biznesu obejmuje ekonomiczne, prawne, etyczne i uznaniowe/filantropijne oczekiwania, jakie społeczeństwo zgłasza wobec organizacji w danym czasie. W definicji tej zidentyfikowano różne kategorie CSR [Carroll, Shabana, 2010, s. 85-86].

Współcześnie również międzynarodowe instytucje i organizacje definiują społeczną odpowiedzialność biznesu na użytek swoich strategii i programów. Definicja CSR przedsiębiorstw zaproponowana przez Komisję Europejską podkreśla, że jest to koncepcja, zgodnie z którą firmy dobrowolnie uwzględniają aspekty społeczne i środowiskowe w swojej działalności biznesowej w ramach stosunków z interesariuszami [www1].

Międzynarodowa Organizacja Normalizacyjna odpowiedzialny biznes definiuje jako odpowiedzialność organizacji za skutki swoich decyzji i działania na rzecz społeczeństwa i środowiska poprzez przezroczyste i etyczne zachowanie, które [www2]:

- przyczynia się do zrównoważonego rozwoju, włączając troskę o ochronę zdrowia i dobrobyt społeczeństwa,

- jest stosowane wobec zainteresowanych stron,

- jest zgodne z prawem i międzynarodowymi normami,

- jest zintegrowane w całej organizacji i stosowane $w$ jej relacjach $z$ otoczeniem.

W dokumencie polskiego Ministerstwa Gospodarki [CSR, s. 6] przyjęto następującą definicję CSR: „Społeczna odpowiedzialność i zobowiązanie organizacji do włączenia aspektów społecznych i środowiskowych w proces podejmowania decyzji oraz wzięcie odpowiedzialności za wpływ podejmowanych decyzji i aktywności na społeczeństwo i środowisko".
CSR obejmuje więc szeroki zakres zachowań, takich jak: przyjazne nastawienie wobec pracowników, wobec środowiska, świadomość zasad etycznych, respektowanie społeczności, w których funkcjonuje firma, a także przyjazne postępowanie wobec inwestorów [Wysokińska, Witkowska, 2016, s. 100].

\section{Społeczna odpowiedzialność biznesu w bankach}

W odniesieniu do banku, społeczna odpowiedzialność biznesu opiera się na służebnej roli banku w gospodarce rynkowej. Wyrazem tego jest bezpieczeństwo działania, które istotne jest nie tylko dla deponentów, ale również dla stabilności gospodarki. Rola służebna banków opiera się na pomaganiu w krążeniu siły nabywczej przy możliwie niskich kosztach transakcyjnych, tj. kosztach związanych z procesem wymiany dóbr w gospodarce. Istotny jest tu związek banków z realną sferą gospodarki rynkowej - jego jakość, zakres, skala i siła [Korenik, 2011, s. 24].

Służebna rola banku to także odpowiedzialność makroekonomiczna polegająca na efektywnym (odpowiedzialnym) przeprowadzaniu wykonywanych czynności bankowych. E. Gostomski zauważa, że bank najlepiej służy gospodarce i państwu przez to, że właściwie pełni swoje funkcje jako pośrednik na rynku finansowym [Gostomski, 2007, s. 47]. W szerszym ujęciu i w odniesieniu do zaprezentowanych koncepcji społecznej odpowiedzialności, bank powinien realizować wspomniane cele komercyjne $z$ uwzględnieniem potrzeb pracowników, lokalnej społeczności oraz wykazywać troskę o środowisko naturalne.

Realizacja idei społecznej odpowiedzialności biznesu zakłada konieczność zrównoważonego wpływu podmiotu, jakim jest współczesny bank, na sferę ekonomiczną, społeczną oraz środowisko naturalne. W przypadku sfery ekonomicznej do kluczowych interesariuszy należy zaliczyć: właścicieli, 
klientów, dostawców, kontrahentów oraz społeczności lokalne; do sfery społecznej: pracowników, klientów oraz społeczności; w obszarze środowiska naturalnego są to: klienci, pracownicy oraz społeczności lokalne [Marcinkowska, 2013, s. 23].

Kwintesencję działalności banków stanowi budowa trwałych relacji z otoczeniem bliższym i dalszym, opartych na zaufaniu. Kapitał relacyjny jest warunkiem koniecznym dla zapewnienia pozycji konkurencyjnej. Podstawą tworzenia wartości banku jest zbudowanie trwałej sieci relacji z interesariuszami.

Wśród głównych kwestii, które są podejmowane w sferze ekonomicznej i społecznej, można wymienić [Zabawa, 2015, s. 184-185]:

- w obszarze ekologii: kontrola odpadów, emisja szkodliwych substancji, zużycie energii, stabilny, zrównoważony wzrost;

- w obszarze społecznym: zaangażowanie w zewnętrzne kwestie społeczne (wykluczenie społeczne, regeneracja społeczno- ści, edukacja kulturalna, wolontariat pracowniczy), polityka dotycząca zasobów ludzkich (równe prawa, prawa człowieka, rozwój, edukacja);

- w obszarze ekonomicznym: wynik finansowy, miejsca pracy, standardy reklamowe.

Społeczna odpowiedzialność banku może być rozpatrywana zarówno na różnych poziomach, jak i w odniesieniu do wybranych obszarów jego działalności. Stopniowalność zaangażowania banku w realizację zasad społecznej odpowiedzialności przedstawiono w tabeli 1.

Najniższy poziom oznacza te rodzaje aktywności, których podjęcie nie wymaga od banku specjalnego wysiłku, czyli społecznie odpowiedzialne reklamowanie oferowanych produktów (np. rzetelna informacja o rzeczywistym oprocentowaniu lokat) lub działalność charytatywna na rzecz lokalnej społeczności.

Tabela 1. Hierarchia działań banku z uwzględnieniem zasad CSR

\begin{tabular}{|l|l|}
\hline \multicolumn{1}{|c|}{ Poziomy } & \multicolumn{1}{c|}{ Wyszczególnienie } \\
\hline Poziom III najwyższy & Oferowanie produktów i usług finansowych powiązanych z zasadami CSR \\
\hline Poziom II & Organizacja pracy i procesu gospodarowania z uwzględnieniem wymogów CSR \\
\hline Poziom I najniższy & Akcje charytatywne, public relations, marketing \\
\hline
\end{tabular}

Źródło: [Krasodomska, 2012, s. 155].

Kolejny poziom dotyczy procesów zachodzących wewnątrz banku, czego przykładem może być społecznie odpowiedzialne traktowanie pracowników, wykorzystywanie odnawialnej energii w codziennym funkcjonowaniu banku, racjonalizacja podróży służbowych poprzez zachętę do korzystania z publicznych środków transportu czy wideokonferencje, wyposażenie oddziałów w towary i usługi spełniające kryteria ekologiczne. Poziom trzeci zakłada oferowanie produktów i usług zgodnych z koncepcją społecznej odpowiedzialności, np. uwzględnianie ryzyka ekologicznego w procesie kredytowania, kredyty termomodernizacyjne, fundusze inwestycyjne uwzględniające aspekty środowiskowe w polityce inwestycyjnej czy też lokacyjne produkty ustrukturyzowane powiązane z ochroną środowiska, np. oparte na indeksach energii odnawialnej [Krasodomska, 2012, s. 155]. Takie rozwiązania ekologicznie przyjazne i ekonomicznie wartościowe służą realizacji idei zrównoważonego rozwoju. Społeczna odpowiedzialność biznesu często jest utożsamiana z koncepcją zrównoważonego rozwoju gospodarczego, który nie narusza w sposób istotny i nieodwracalny środowiska życia człowieka godząc w prawa przyrody i ekonomii. 
Niezwykle ważną cechą relacji między klientami a bankami jest kultura zaufania publicznego, która warunkuje rozwój i przetrwanie banków. Wyróżniamy trzy płaszczyzny budowy zaufania publicznego: więzi osobiste, kodeksy deontologiczne (kodeks dobrej praktyki bankowej) oraz system prawny rynków finansowych [Masiukiewicz, 2007, s. 4]. Przestrzeganie zasad etycznych w praktyce bankowej powinno być realizowane poprzez uczciwą i przejrzystą ofertę bankową, rzetelny przekaz informacji zawartych w materiałach promocyjnych, bezstronne i uczciwe zasady załatwiania reklamacji oraz kształtowanie etycznych relacji z konkurencją.

Obecnie wśród najbardziej istotnych obszarów w zakresie społecznej odpowiedzialności współczesnych banków - obok poszanowania środowiska naturalnego - należy wymienić: edukację finansową społeczeństwa, przeciwdziałanie wykluczeniu finansowemu, jak również odpowiedzialne kredytowanie oraz przeciwdziałanie nadmiernemu zadłużeniu [Zabawa, 2015, s. 185].

\section{Społeczna odpowiedzialność biznesu w bankach spółdzielczych}

W sektorze bankowości spółdzielczej społeczna odpowiedzialność biznesu jest częścią filozofii ich działania oraz codziennej praktyki gospodarczej. Ponadto, w strategię banków spółdzielczych wpisana jest społeczna odpowiedzialność biznesu od samego początku ich funkcjonowania. Banki spółdzielcze uwzględniają interesy społeczne i relacje ze środowiskiem lokalnym. Przykładem może być współpraca na linii bank - szkoła, bank - lokalna grupa działania, bank - instytucje pozarządowe, bank - organizacje społeczne. Idea ta jest realizowana poprzez następujące działania [Nowacka i inni, 2017, s. 57]:

- rozwiązywanie i uwzględnianie następstw ekologicznych w organizowaniu działalności gospodarczej,
- budowanie zaufania publicznego poprzez przestrzeganie zasad etycznych w praktyce bankowej,

- rozwijanie i utrzymywanie miejsc pracy w lokalnych placówkach,

- promowanie lokalnego rozwoju gospodarczego i finansowego poprzez dostosowanie oferty produktowej i usługowej,

- edukacja prowadzona przez banki,

- zapobieganie wykluczeniu finansowemu.

Banki spółdzielcze sięgają po różne rozwiązania wspierające finansowanie inwestycji z zakresu ochrony środowiska. Są to m.in.: depozyty celowe, które wyróżnia przeznaczenie, udziałowe papiery wartościowe, a przede wszystkim kredyty bankowe. Mogą być one udzielane przez banki na warunkach:

- rynkowych - gdy przedsięwzięcie spełnia ogólne wymogi (głównie ekonomiczne),

- preferencyjnych - gdy przedsięwzięcie spełnia wymogi głównie ekologiczne, a w mniejszym stopniu ekonomiczne i dlatego projekt wymaga wsparcia.

Banki spółdzielcze angażują się w kredytowanie inwestycji na rzecz ochrony środowiska, głównie na zakup kolektorów słonecznych służących do ogrzewania wody użytkowej lub wspomagania zasilania w energię innych odbiorników ciepła w budynkach wykorzystywanych na cele mieszkaniowe. Ponadto kredytowany jest zakup przydomowych oczyszczalni ścieków lub podłączanie jak największej liczby gospodarstw domowych do istniejących instalacji kanalizacyjnych zbudowanych przez gminy.

W relacjach z klientami banki spółdzielcze starają się uwzględniać szczególne zaufanie, jakim są darzone poprzez wysokie wymagania co do rzetelności i starannego traktowania wszystkich klientów. Podejmowanie działań w tym zakresie postulowane jest w zasadach dobrej praktyki bankowej. Jest to zbiór norm postępowania dotyczący działalności banków i odnoszący się do osób zatrudnionych w bankach oraz także do osób pośredniczących w czynnościach bankowych, tj. działających 
na rzecz banków i w ich imieniu [Strzelecki, 2008, s. 115]. Zasady te zawierają [ibidem]:

- zasady postępowania banków z klientami,

- zasady wzajemnych stosunków między bankami,

- zasady reklamy, zasady postępowania pracowników banku,

- postanowienia dotyczące Komisji Etyki Bankowej, wraz z załączonym regulaminem Komisji Etyki Bankowej.

Skuteczność działania banku spółdzielczego zależy od profesjonalnej wiedzy pracowników oraz ich przedsiębiorczości. Gdy poziom kwalifikacji pracowników wzrasta, maleje wykorzystywanie przez nich doświadczeń z przeszłości oraz tzw. zdroworozsądkowe podejście do rozwiązywania problemów. Coraz częściej przy podejmowaniu strategicznych decyzji, kierowaniu zespołem czy negocjacjach wykorzystywane są podstawy zarządzania, socjologii oraz psychologii. Zaufanie publiczne do banku budowane jest również poprzez:

- uczciwość, pracowitość i kompetencje zarządu oraz personelu banku,

- zachowanie przez pracowników tajemnicy bankowej.

Zatrudnienie w sektorze bankowości spółdzielczej utrzymuje się na wysokim poziomie w stosunku do udziału sektora w rynku. Przekłada się to na lepszą opiekę nad klientem. Pracownicy banków spółdzielczych cieszą się dużym zaufaniem klientów, dla których szczególnie istotna jest szybkość podejmowania decyzji kredytowych. Ich szeroka wiedza na temat produktów oraz klientów często wynika z długiego stażu pracy. Ta wiedza pracowników ułatwia szybkie i bezpieczne podejmowanie decyzji i jest jednym z najcenniejszych atutów bankowości spółdzielczej [Olszewski, Morye, 2013, s. 6]. Pracownicy banków spółdzielczych to najczęściej osoby z lokalnego środowiska, sąsiedzi lub znajomi klientów. Dzięki temu kontakty nie mają tylko charakteru biznesowego.
Ponadto podmiotowe podejście do klienta i umiejętność rozpoznania jego potrzeb oraz oczekiwań sprzyjają budowaniu stabilnej pozycji całego banku.

Banki spółdzielcze są najczęściej podmiotami funkcjonującymi na rynku lokalnym lub regionalnym. Ich model biznesowy oparty jest na bankowości relacyjnej, decentralizacji i zrozumieniu potrzeb lokalnej społeczności.

Obsługując miejscowych mieszkańców oraz małe i średnie firmy wspierają rozwój swoich środowisk. Dostarczając klientom różnorodnych informacji, ułatwiają im prowadzenie działalności gospodarczej. Banki spółdzielcze odgrywają ogromne znaczenie w obsłudze finansowo-kredytowej elementów infrastruktury technicznej, np. budowy wodociągów, dróg itp. Jej unowocześnienie sprzyja wzrostowi pozarolniczej działalności gospodarczej ludności wiejskiej, co przyczynia się do lepszego wykorzystania lokalnych zasobów surowcowych, zaspokojenia rynku konsumpcyjnego, wykorzystania walorów rekreacyjnych, podnoszenia dochodów oraz ograniczenia i likwidacji bezrobocia [Siudek, Śledź, 1998, s. 57].

Ponadto banki spółdzielcze od dawna prowadzą aktywny proces edukacji społeczności lokalnej, która przybiera różne formy, jak prelekcje czy prezentacje skierowane do młodzieży. Te inicjatywy pozwalają młodym ludziom zrozumieć, na czym polega oszczędzanie, jak działają rachunki bankowe, karty płatnicze, bankowość mobilna i internetowa. Młodzi, którzy są bardziej otwarci na nowe technologie i rozwiązania oraz formy komunikacji, często edukują swoich rodziców i dziadków. Pokazują, jak łatwe jest korzystanie z bankowości mobilnej czy internetowej oraz zachęcają swoich bliskich do posiadania kart płatniczych. Przy tym podnoszona jest bardzo ważna kwestia, jaką jest bezpieczeństwo finansowe. Pracownik banku nigdy nie będzie tak wiarygodny jak najbliższa rodzina, dlatego tak ważny jest proces edukacji [Nowacka i inni, 2017, s. 60-61]. 


\section{Opinia klientów na temat społecznej odpowiedzialności biznesu w bankach spółdzielczych}

Celem badania przeprowadzonego wśród klientów banków spółdzielczych było poznanie ich opinii na temat zakresu usług bankowych, z jakich korzystają oraz społecznego wymiaru funkcjonowania banków spółdzielczych.

Przeprowadzone badania obejmowały następujące zagadnienia:

1. Identyfikacja społecznych aspektów funkcjonowania banków spółdzielczych.

2. Ocena realizacji koncepcji biznesu społecznie odpowiedzialnego $\mathrm{w}$ bankach spółdzielczych.

3. Inicjatywy banków spółdzielczych wpływające na rozwój społeczno-gospodarczy w wymiarze lokalnym i regionalnym.

4. Poznanie opinii klientów banków spółdzielczych na temat usług bankowych.

Badanie ankietowe zostało przeprowadzone we wrześniu i październiku 2015 r. wśród klientów wybranych banków spółdzielczych, zlokalizowanych na terenie powiatu płockiego (województwo mazowieckie) i żywieckiego (województwo śląskie). Kwestionariusz ankiety składał się z 29 pytań zamkniętych, półotwartych i otwartych. Klienci objęci badaniem zostali wybrani metodą doboru wygodnego [Hill, Aleksander, 2003 , s. 126]. O wypełnienie ankiety poproszeni zostali klienci 11 placówek banków spółdzielczych, którzy wychodzili z banku i wyrażali chęć udzielenia odpowiedzi na zawarte w kwestionariuszu pytania. Łącznie przebadanych zostało 99 osób z województwa mazowieckiego i 32 z województwa śląskiego. Próba miała charakter niereprezentatywny. Obliczenia wykonano w programie IBM SPSS 23.0. Jako poziom istotności statystycznej przyjęto $p<0,05$.

W badaniu uczestniczyło 58 mężczyzn i 74 kobiety, co stanowiło odpowiednio
43,5 i $56,5 \%$ próby. 22 osoby uplasowały się w przedziale wiekowym 18-25 lat, 25 respondentów było z przedziału wiekowego 26-35 lat, 34 osoby w przedziale 36-45 lat, 28 osób w przedziale wiekowym 46-55 lat, 18 respondentów w przedziale 56-65 lat i 5 osób powyżej 66 lat. Większość osób zamieszkiwała wieś, to jest 54 osoby, wieś gminną - 50 osób. Najwięcej osób posiadało wykształcenie wyższe zawodowe (30 osób) i średnie zawodowe (29 osób). 59 osób posiadało stałą pracę. $Z$ reguły osoby te były rolnikami $(25$ osób) i pracownikami fizycznymi (26 osób). Najwięcej osób, to jest 37, deklarowało uzyskiwanie miesięcznego dochodu netto na osobę w przedziale 1001-1500 zł.

W bankach spółdzielczych odpowiedzialny biznes przyczynia się niewątpliwie do zwiększenia wiarygodności i budowania kapitału społecznego, a tym samym prowadzi do poprawy wizerunku podmiotu. Za istotne korzyści uznaje się także poprawę relacji z lokalną społecznością i wzrost zaufania klientów. Kompetencje w zakresie kształtowania relacji z otoczeniem mogą stanowić o przewadze konkurencyjnej banków spółdzielczych i są niezbędne do tworzenia ich wartości.

Respondentów zapytano, czy ich bank spółdzielczy wspiera inicjatywy społeczne (tabela 2).

Ponad 50\% ankietowanych klientów uważało, że ich bank spółdzielczy wspiera lokalne inicjatywy społeczne. Przeciwnego zdania było 37,9\% respondentów. Rozkład odpowiedzi wskazuje, że banki spółdzielcze są postrzegane przez klientów jako instytucje identyfikujące się z lokalnymi społecznościami, ich problemami i specyfiką, które chętnie podejmują działania mające na celu rozwój inicjatyw środowiska, w którym funkcjonują.

W dalszej części ankiety poproszono klientów o wskazanie inicjatyw społecznych, które banki spółdzielcze wspierają (wykres 1). 
Tabela 2. Wspieranie inicjatyw społecznych przez bank spółdzielczy

\begin{tabular}{|l|c|c|}
\hline \multicolumn{1}{|c|}{ Czy banki spółdzielcze wspierają inicjatywy społeczne? } & Liczba & Procent \\
\hline Tak & 75 & 56,8 \\
\hline Nie & 50 & 37,9 \\
\hline Brak odpowiedzi & 7 & 5,3 \\
\hline Ogółem & 132 & 100 \\
\hline
\end{tabular}

Źródło: badania własne.

\section{Wykres 1. Formy wspierania inicjatyw społecznych przez banki spółdzielcze według oceny \\ klientów banków}

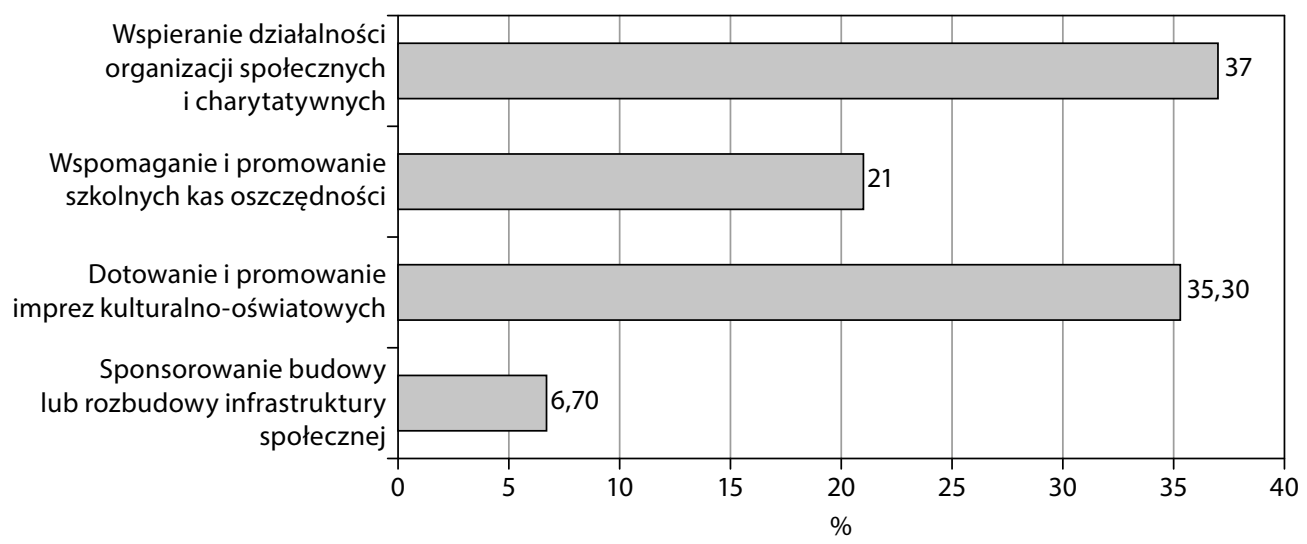

Źródło: badania własne.

Z uzyskanych odpowiedzi wynika, że banki spółdzielcze najczęściej dotują i promują imprezy kulturalno-oświatowe $(35,3 \%)$ oraz wspierają działalność organizacji społecznych i charytatywnych (37\%). Wysoką aktywność banków spółdzielczych we wspieraniu takich form przedsięwzięć na rzecz społeczności lokalnych potwierdzają wyniki wcześniejszych badań [Stefański, 2012, s. 137].

Klienci banków spółdzielczych chętnie uczestniczą w różnych imprezach sponsorowanych przez te instytucje, o czym świadczy rozkład odpowiedzi zaprezentowany w tabelach 3 i 4.

Prawie połowa respondentów, którzy udzielili odpowiedzi, deklaruje uczestnictwo w imprezach sponsorowanych przez bank spółdzielczy. Największy odsetek odpowiedzi twierdzących uzyskano w grupie osób z wykształceniem wyższym zawodowym $(31,7 \%)$ oraz ze średnim zawodowym (15\%). Najmniejsze zainteresowanie odnotowano wśród osób z wykształceniem podstawowym $(4,5 \%)$ i wyższym magisterskim $(6,1 \%)$. Rozkład odpowiedzi twierdzących może wynikać z faktu, że osoby z wykształceniem średnim i wyższym zawodowym stanowiły najliczniejszą grupę wśród badanych klientów banków spółdzielczych. Dlatego też te osoby najczęściej uczestniczyły w imprezach sponsorowanych przez banki spółdzielcze.

Dane zawarte w tabeli 4 wskazują, że najliczniejszą grupę uczestników imprez sponsorowanych przez bank spółdzielczy stanowią osoby dysponujące dochodem miesięcznym powyżej 2000 zł. Takiej odpowiedzi udzieliło 35,6\% respondentów. W grupie osób, które nie uczestniczyły w imprezach sponsorowa- 
nych przez bank spółdzielczy rozkład odpowiedzi jest odwrotny. Najliczniejszą grupę stanowią respondenci uzyskujący dochód netto na osobę w przedziale do 1000 zł - 40,8\%.
Można więc zauważyć tendencję, że im wyższy dochód na osobę w gospodarstwie domowym, tym częstsze korzystanie z imprez sponsorowanych przez bank spółdzielczy.

\section{Tabela 3. Zależność między udziałem w imprezach sponsorowanych przez bank} spółdzielczy a wykształceniem respondentów

\begin{tabular}{|l|c|c|c|c|c|c|c|c|}
\hline \multicolumn{2}{|c|}{$\begin{array}{c}\text { Udział w imprezach } \\
\text { sponsorowanych przez } \\
\text { bank spółdzielczy }\end{array}$} & Podstawowe & $\begin{array}{c}\text { Zasadnicze } \\
\text { zawodowe }\end{array}$ & $\begin{array}{c}\text { Średnie } \\
\text { zawodowe }\end{array}$ & $\begin{array}{c}\text { Średnie } \\
\text { ogólno- } \\
\text { kształcące }\end{array}$ & $\begin{array}{c}\text { Wyższe } \\
\text { zawodowe }\end{array}$ & $\begin{array}{c}\text { Wyższe } \\
\text { magisterskie }\end{array}$ & 0gółem \\
\hline \multirow{2}{*}{ Nie } & $\mathrm{N}$ & 3 & 19 & 14 & 15 & 11 & 4 & 66 \\
\cline { 2 - 9 } & $\%$ & $4,5 \%$ & $28,8 \%$ & $21,2 \%$ & $22,7 \%$ & $16,7 \%$ & $6,1 \%$ & $52,4 \%$ \\
\hline \multirow{2}{*}{ Tak } & $\mathrm{N}$ & 1 & 9 & 15 & 5 & 19 & 11 & 60 \\
\cline { 2 - 9 } & $\%$ & $1,7 \%$ & $15 \%$ & $25 \%$ & $8,3 \%$ & $31,7 \%$ & $18,3 \%$ & $47,6 \%$ \\
\hline 0gółem & $\mathrm{N}$ & 4 & 28 & 29 & 20 & 30 & 15 & 126 \\
\cline { 2 - 9 } & $\%$ & $3,2 \%$ & $22,2 \%$ & $23,0 \%$ & $15,9 \%$ & $23,8 \%$ & $11,9 \%$ & $100 \%$ \\
\hline
\end{tabular}

$X^{2}=14,754 ; d f=5 ; p=0,011 ;$ test istotny przy $p<0,05$

Żródło: badanie własne.

Tabela 4. Zależność między udziałem w imprezach sponsorowanych przez bank spółdzielczy a przybliżonym dochodem netto na osobę w gospodarstwie domowym respondentów

\begin{tabular}{|c|c|c|c|c|c|c|}
\hline \multirow{2}{*}{\multicolumn{2}{|c|}{$\begin{array}{l}\text { Udział w imprezach } \\
\text { sponsorowanych przez bank } \\
\text { spółdzielczy }\end{array}$}} & \multicolumn{4}{|c|}{$\begin{array}{l}\text { Przybliżony miesięczny dochód netto na osobę w gospodarstwie } \\
\text { domowym }\end{array}$} & \multirow{3}{*}{$\begin{array}{c}\text { Ogółem } \\
71\end{array}$} \\
\hline & & \multirow{2}{*}{$\frac{\text { do } 1000 \mathrm{z} \nmid}{29}$} & \multirow{2}{*}{$\begin{array}{c}1001-1500 \mathrm{zł} \\
28\end{array}$} & \multirow{2}{*}{$\frac{1501-2000 \text { zł }}{8}$} & \multirow{2}{*}{$\frac{2000 \text { zł i więcej }}{6}$} & \\
\hline Nie & $\mathrm{N}$ & & & & & \\
\hline & $\%$ & $40,8 \%$ & $39,4 \%$ & $11,3 \%$ & $8,5 \%$ & $54,6 \%$ \\
\hline \multirow[t]{2}{*}{ Tak } & $\mathrm{N}$ & 15 & 9 & 14 & 21 & 59 \\
\hline & $\%$ & $25,4 \%$ & $15,3 \%$ & $23,7 \%$ & $35,6 \%$ & $45,4 \%$ \\
\hline \multirow[t]{2}{*}{ Ogółem } & $\mathrm{N}$ & 44 & 37 & 22 & 27 & 130 \\
\hline & $\%$ & $33,8 \%$ & $28,5 \%$ & $16,9 \%$ & $20,8 \%$ & $100 \%$ \\
\hline
\end{tabular}

$x^{2}=23,272 ; d f=3 ; p=0,000 ;$ test istotny przy $p<0,05$

Źródło: badanie własne.

Analiza wyników badania ankietowego wskazuje, że pozostałe cechy społeczno-demograficzne, takie jak: miejsce zamieszkania, wiek, płeć, obecna sytuacja zawodowa, przynależność do grupy społeczno-zawodowej nie miały wpływu na rozkład odpowiedzi respondentów w zakresie objętym powyższym pytaniem.
Wachlarz imprez sponsorowanych przez banki spółdzielcze jest relatywnie szeroki. $\mathrm{Na}$ wykresie 2 zaprezentowano odpowiedzi ankietowanych klientów ze wskazaniem popularności, jaką cieszyły się poszczególne inicjatywy banków. 


\section{Wykres 2. Rodzaje imprez sponsorowanych przez banki spółdzielcze, w których uczestniczyli ich klienci}

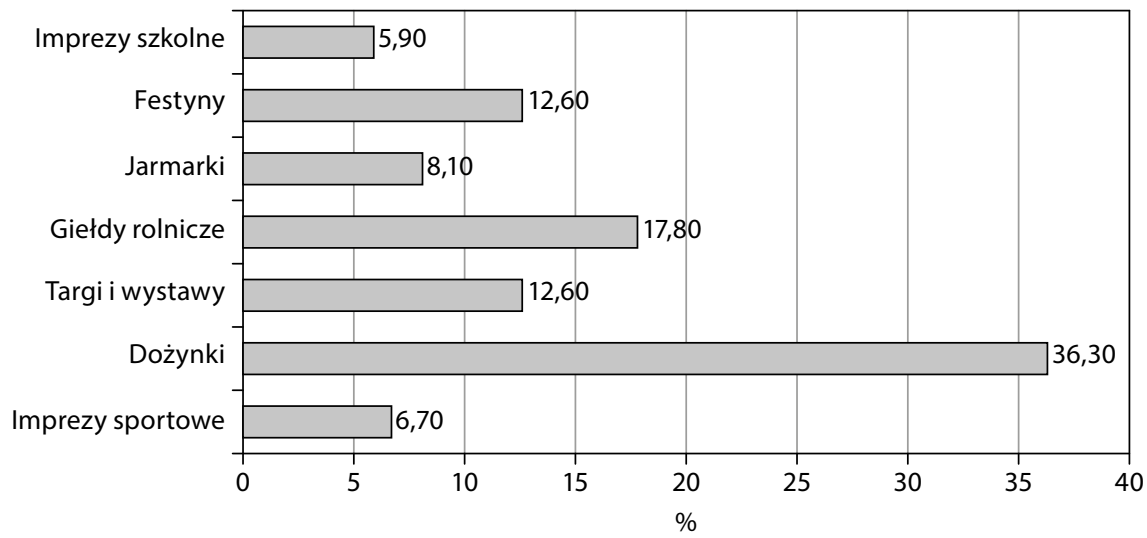

Źródło: badanie własne.

Respondenci najczęściej wskazywali dożynki - 36,3\% oraz giełdy rolnicze - 17,8\%, a najrzadziej imprezy sportowe - 5,9\%. Lokalny charakter działalności oraz umiejscowienie banków spółdzielczych w małych miejscowościach na terenach wiejskich wyznaczają kierunek działań tych instytucji w obszarze CSR. Jedną z najliczniejszych grup klientów spółdzielczego sektora bankowego są rolnicy i przedsiębiorcy z sektora rolno-spożywczego. Dlatego też zakres inicjatyw banków spółdzielczych jest skierowany do tych społeczności.

\section{Podsumowanie}

Banki spółdzielcze wpisują się w koncepcję społecznej gospodarki rynkowej nie tylko poprzez tworzenie miejsc pracy, budowanie konkurencyjności gospodarki, ale też odpowiednią strukturę własnościową, specyfikę tych banków, które wypełniają misję pośrednictwa finansowego, szczególnie na rynkach lokalnych, i gospodarowania częścią bogactwa obywateli, instytucji i firm.

Jako podmioty ekonomii społecznej podejmują one szereg inicjatyw społecznych, co potwierdzają przeprowadzone badania. Często współfinansują imprezy kulturalne, oświatowe i sportowe; wspierają finansowo szkoły, przedszkola, kluby sportowe, ochotniczą straż pożarną, stowarzyszenia, biblioteki. W opinii klientów, bank spółdzielczy jest instytucją godną zaufania, o długiej tradycji i stabilności. Często wskazywanym kryterium wyboru tego banku jest bliskość placówek oraz miła i profesjonalna obsługa. Niezaprzeczalnym atutem banków spółdzielczych jest znajomość realiów rynku lokalnego.

Przeprowadzone badania pokazują, że klienci doceniają działania banków spółdzielczych w obszarze społecznej odpowiedzialności biznesu. Ponad połowa respondentów dostrzega zaangażowanie banków spółdzielczych we wspieranie inicjatyw społecznych. Najczęściej wskazywano dotowanie i promowanie imprez kulturalno-oświatowych oraz wspieranie działalności organizacji społecznych i charytatywnych. Ankietowani klienci chętnie uczestniczą w imprezach sponsorowanych przez banki spółdzielcze.

Należy zauważyć, że banki spółdzielcze starają się wypełniać swoją misję społeczną poprzez działanie na rzecz swoich klientów, członków oraz środowiska lokalnego. Często realizują zadania, którymi inne instytucje finansowe lub podmioty gospodarcze nie są zainteresowane, np. zapobiegają wyklu- 
czeniu finansowemu, wspomagają rozwój lokalny, służą budowaniu lokalnych więzi społecznych. Siłą tego sektora jest indywidu-

\section{Literatura}

Benabou R., Tirole J. (2010). „Individual and Corporate Social Responsibility", Economica, nr 77 (s. 1-19).

Bartkowiak G. (2011). Społeczna odpowiedzialność biznesu w aspekcie teoretycznym i empirycznym. Warszawa: Difin.

Carroll A.B., Shabana K.M. (2010). "The Business Case for Corporate Social Responsibility: A Review of Concepts, Research and Practice", International Journal of Management Reviews, vol. 12, iss. 1 (s. 85-105).

CSR. Społeczna odpowiedzialność biznesu w Polsce, Krajowy Program Reform Europa 2020. Warszawa: Ministerstwo Gospodarki, http://bizneszsercem.pl/web/test/CSR_w_Polsce.pdf.

Gostomski E. (2007). "Nie tylko ekonomia”, Gazeta Bankowa, nr 44 (s. 46-47).

Korenik D. (2011). „Refleksja na temat społecznej odpowiedzialności banku komercyjnego", Bezpieczny Bank, nr 3 (45), (s. 22-41).

Krasodomska J. (2012). „Znaczenie społecznej odpowiedzialności banków dla bezpieczeństwa finansowego", Zeszyty Naukowe. Polskie Towarzystwo Ekonomiczne, $\mathrm{nr} 12$ (s. 151-159).

Marcinkowska M. (2013). Kapitat relacyjny banku. Tom I, II, III. Łódź: Wydawnictwo Uniwersytetu Łódzkiego.

Masiukiewicz P. (2007). „Zaufanie publiczne jako wartość w banku", Bank i Rolnictwo, nr 2 (s. 3-5).

Nowacka A., Szewczyk-Jarocka M., Kaczmarczyk P., Grzywacz J. (2017). Banki spółdzielcze w społecznej gospodarce rynkowej. Płock: Wydawnictwo Naukowe Państwowej Wyższej Szkoły Zawodowej w Płocku. alne podejście do klienta, umiejętność budowania relacji, w której klient rozpoznawany jest niemalże imiennie i tak obsługiwany.
Olszewski K., Morye I. (2013), "Najważniejsi są ludzie, nie systemy", Bank Wspólnych Sit, nr 5 (s. 4-6).

Siudek T., Śledź A. (1998). Rola spółdzielczości bankowej w finansowaniu rolnictwa w wybranych krajach Unii Europejskiej i w Polsce. „Banki Hiszpanii i Polski oraz ich funkcjonowanie w warunkach integracji z Unią Europejską", III Seminarium Międzynarodowe Alicante - Hiszpania, 25-30 października 1998 r. Warszawa: Fundacja "Rozwój SGGW".

Stefański M. (2012). „Znaczenie banków spółdzielczych w rozwoju lokalnej przedsiębiorczości i innowacji", w: M. Stefański (red.), Wybrane historyczne i współczesne aspekty rozwoju banków spółdzielczych w Polsce, Włocławek: Wydawnictwo Wyższej Szkoły Humanistyczno-Ekonomicznej we Włocławku.

Strzelecki A. (2008). „Aspekty etyczne działalności banków spółdzielczych", w: M. Stefański (red.), Perspektywy rozwoju bankowości spółdzielczej w Polsce (s. 109-134). Włocławek: Wydawnictwo Wyższej Szkoły Humanistyczno-Ekonomicznej we Włocławku.

Wysokińska Z., Witkowska J. (2016). Zrównoważony rozwój. Wybrane aspekty makro- i mikroekonomiczne. Łódź: Wydawnictwo Uniwersytetu Łódzkiego.

Zabawa J. (2015). „Postrzeganie społecznej odpowiedzialności banków przez ich klientów. Perspektywa ekologiczna", Studia Ekonomiczne. Zeszyty Naukowe Uniwersytetu Ekonomicznego w Katowicach, nr 239 (s. 181-196).

www1: Sustainable and responsible business. European Commission, http://ec.europa.eu/enterprise/ policies/sustainable-business/corporate-social-responsibility/index_en.htm (dostęp: 28.07.2017).

www2: http://www.iso.org/iso/home/standards/ iso26000.htm (dostęp: 28.07.2017).

\section{Perception of corporate social responsibility in a cooperative banks by their clients}

Summary: The concept of corporate social responsibility is part of the strategy of cooperative banks since they were set up. The cooperative character of these institutions and their willingness to compete with other financial market players reflect the main assumptions of CSR. Cooperative banks, while pursuing their mission and vision, try to combine commercial goals with the social dimension of their business.

The main purpose of the article is to present opinions of clients of cooperative banks on the implementation of corporate social responsibility by these institutions. The author attempts to answer the question, whether customers perceive the social aspect of cooperative banks operation and how they assess their approach to running a business.

The empirical basis for the issues discussed in the article is a study of the literature on the subject and the survey results of 132 clients of selected cooperative banks. The questions concerned include: social initiatives undertaken by cooperative banks, forms of support provided by these institutions and participation of clients in events sponsored by cooperative banks. To develop the research results the following methods have been used: structural indicators and chi-squared compliance test. 
Following the results of the conducted research the general conclusion have been drawn. The most important of these is the fact, that the clients recognize social initiatives undertaken by cooperative banks. They appreciate the involvement of these institutions in promoting cultural and educational events as well as supporting and donating to social and charitable organizations. The idea of CSR is also realized through the process of financial education of the local community, and youth in particular.

Keywords: cooperative banks, corporate social responsibility, social economy, clients.

\section{Prawa autorskie i licencja / Copyright and License}

Artykuł opublikowano na licencji Creative Commons

Uznanie autorstwa - Użycie niekomercyjne - Bez utworów zależnych 3.0 Polska

http://creativecommons.org/licenses/by-nc-nd/3.0/pl/

This article is published under the terms of the Creative Commons

Attribution - NonCommercial - NoDerivs (CC BY-NC-ND 3.0) License

http://creativecommons.org/licenses/by-nc-nd/3.0/ 